Article

\title{
Nitrogen Utilization from Ammonium Nitrate and Urea Fertilizer by Irrigated Sugarcane in Brazilian Cerrado Oxisol
}

\author{
Nelmício Furtado da Silva ${ }^{1, *}$, Edson Cabral da Silva ${ }^{1}$ (D) Takashi Muraoka ${ }^{2}$, \\ Marconi Batista Teixeira ${ }^{1}$, Frederico Antonio Loureiro Soares ${ }^{1}$, Fernando Nobre Cunha ${ }^{1}$, \\ Joseph Adu-Gyamfi ${ }^{3}$ and Wendson Soares da Silva Cavalcante ${ }^{4}$ \\ 1 Instituto Federal Goiano-Campus Rio Verde, Rodovia Sul Goiana, Km 01, \\ CEP 75901-970 Rio Verde, GO, Brazil; edsoncabralsilva@gmail.com (E.C.d.S.); \\ marconibt@gmail.com (M.B.T.); fredalsoares@gmail.com (F.A.L.S.); \\ fernandonobrecunha@hotmail.com (F.N.C.) \\ 2 Centro de Energia Nuclear na Agricultura, Universidade de São Paulo, Av. Centenário, Numbe. 303, \\ CEP 13416-000 Piracicaba, SP, Brazil; muraoka@cena.usp.br \\ 3 Soil and Water Management \& Crop Nutrition Subprogram, Joint FAO/IAEA Division of Nuclear Techniques \\ in Food and Agriculture, International Atomic Energy Agency, IAEA, 1400 Vienna, Austria; \\ J.Adu-Gyamfi@iaea.org \\ 4 Faculdade UniBRÁS-Rio Verde, R. Doze de Outubro, Number. 42, CEP 75906-577 Rio Verde, GO, Brazil; \\ wendsonbfsoarescvt@gmail.com \\ * Correspondence: nelmiciofurtado@gmail.com
}

Received: 29 May 2020; Accepted: 29 July 2020; Published: 2 August 2020

\begin{abstract}
Sugarcane is the most promising among renewable biofuel-producing crops. An adequate availability of water and nutrients, especially nitrogen $(\mathrm{N})$, is of utmost importance. From the hypothesis that the source and the rate of $\mathrm{N}$ fertilization influence the $\mathrm{N}$ use efficiency of an irrigated soil-sugarcane system, this study aimed to evaluate the stalk and crop residues (pointer and leaves) yield, as well as the $\mathrm{N}$ utilization, from different rates of ammonium nitrate and urea by irrigated sugarcane in the cane plant cycle, using an ${ }^{15} \mathrm{~N}$ isotopic dilution technique. The soil used for the experiment was an Oxisol (Rhodic Haplustox) Cerrado (savannah) phase. The experiment was carried out at a farm of the Raízen Mill, which was located in the municipality of Jataí, Goias State, Brazil. The sugarcane variety IACSP95-5000 was used in a randomized block design, with three replicates, four $\mathrm{N}$ rates $\left(30,60,120\right.$, and $180 \mathrm{~kg} \mathrm{ha}^{-1}$ ), and two fertilizer sources labeled with ${ }^{15} \mathrm{~N}$ isotopes (urea and ammonium nitrate). The average value for $\mathrm{N}$ utilization was $60.17 \%$ for the ammonium nitrate source and $44.95 \%$ for urea. The responses in the percentage and quantity of $\mathrm{N}$ in the sugarcane from the fertilizer increase with the increasing $\mathrm{N}$ rate. The soil was the main $\mathrm{N}$ source for sugarcane. The higher stalk and pointer yield was recorded at the average rate of $143.61 \mathrm{~kg} \mathrm{~N} \mathrm{ha}^{-1}$. Further studies are needed to evaluate the residual effect of $\mathrm{N}$ in the next cycles.
\end{abstract}

Keywords: Saccharum spp.; stalk yield; N recovery; nitrogen-15; Oxisol; cerrado

\section{Introduction}

Sugarcane (Saccharum spp.) is socio-economically a very important crop for Brazil. It is considered one of the main agricultural commodities grown in tropical and subtropical regions. It is used as a raw material mainly for the production of sugar and biofuel. Brazil is highlighted in the production of this culture and its derivatives, being the world's largest producer. According to the last survey conducted by the National Supply Survey Company [1], the estimated production of sugarcane in the 
2019/2020 harvest is 642.7 million tons in an area of 8.5 million hectares, providing a yield of $75.78 \mathrm{tha}^{-1}$. It is important to highlight that this value is below the productive potential of this crop. The current low productivity of the crop is related to several factors, among them mineral nutrition and a poor distribution of rainfalls [1]. The Brazilian Cerrado (Savannah) area comprises about 204.7 million hectares, which is equivalent to $23.3 \%$ of the country land, being the main area for expanding of sugarcane cropping in Brazil [1]. These data justify studies that use tools such as irrigation and nitrogen fertilization, as the proper management of irrigation and nitrogen fertilization promotes an increase in the productive potential of sugarcane.

In 2018, Brazilian agribusiness promoted an export of 7.4 billion dollars in products from the sugar and alcohol complex, representing $7.3 \%$ of total exports [2]. The growing demand for food production has resulted in an overuse of agricultural resources, among which nitrogen $(\mathrm{N})$ can be considered one of the most yield-limiting factors for maximum yield [3,4].

Sugarcane is the most important crop in the Brazilian energy scenario, and $\mathrm{N}$ fertilization stands out as one of the most studied cultural practices in this crop. In spite of this, the great $\mathrm{N}$ demand, high financial and energy cost of $\mathrm{N}$ fertilizers, environmental risks related to the addition of mineral $\mathrm{N}$ in the system, and other questions have led to several studies on $\mathrm{N}$ fertilization in sugarcane [5]. In addition, sugarcane cultivation has undergone changes in the management practices in the field, the main one of which is the transition from manual harvest with previous burning of the sugarcane field to mechanized harvest without fire extinguishing. The harvest without burning ensures the permanence of the plant residues (dry leaves and pointers) of the species on the soil, and it changes the dynamics of mineralization-immobilization of $\mathrm{N}$ in the sugarcane systems. In addition, $\mathrm{N}$-organic mineralization has a positive effect on plant nutrition [6-8].

Very dynamic in the soil and involved in many processes, nitrogen is an important nutrient that is involved in the process of ammonification, nitrification, denitrification, and mineralization $[9,10]$. Low nitrogen use efficiency (NUE) is likely to occur as a result of inadequate fertilizer management practices, such as the application of inadequate rates, broadcast application without incorporation, or excessively high rates applied to poorly drained soils [11,12]. Inadequate $\mathrm{N}$ management has contributed to increased $\mathrm{N}$ losses by ammonia $\left(\mathrm{NH}_{3}\right)$ volatilization, nitrate $\left(\mathrm{NO}_{3}\right)$ leaching, and nitrous oxide $\left(\mathrm{N}_{2} \mathrm{O}\right)$ emissions, which have both economic and environmental consequences [13-15].

Sugarcane is cultivated in Brazil with the application of $\mathrm{N}$-fertilizer rates much lower than those of other sugarcane-producing countries [5]. $\mathrm{N}$ fertilization may promote increased productivity in the cane plant $[16,17]$. However, in general, the response is low, which is mainly due to the incorporation of crop residues and improvements in the soil fertility conditions with the re-planting of the sugarcane $[5,18,19]$. Despite technological improvements in plant nutrition, soil management, and machinery, for example, the use of no-tillage system, cover crops, and crop rotation to increase sustainability in Brazilian agricultural system, nutrient management strategies should be improved, in particular $\mathrm{N}$ management $[20,21]$.

According to [22], for a yield of $100 \mathrm{tha}^{-1}$ of stalks, the crop extracts around $200-300 \mathrm{~kg} \mathrm{ha}^{-1}$ of $\mathrm{N}$. The amounts of $\mathrm{N}$ exported by the stalks are similar or even lower than the nutrient applied along the cycle, not counting the $\mathrm{N}$ losses from the soil-plant system [5]. A number of compositions of $\mathrm{N}$ in the plant were found, and the extraction and export varied between varieties [23] and water availability [24-26]. The $\mathrm{N}$ use efficiency or recovery of $\mathrm{N}$ applied as fertilizer by sugarcane or other vegetables depends on the form and place of application, precipitation, variety [23], and applied $\mathrm{N}$ source [27].

The stable isotope of nitrogen $\left({ }^{15} \mathrm{~N}\right)$ occurs in nature at lower concentrations than its ${ }^{14} \mathrm{~N}$ counterpart. The use of the $\mathrm{N}$ isotopes is based on the fact that the ratio ${ }^{14} \mathrm{~N} /{ }^{15} \mathrm{~N}$ occurs naturally at a nearly constant ratio of $273: 1\left(0.3663 \%\right.$ of ${ }^{15} \mathrm{~N}$ atoms). Techniques based on the measurement of the relative concentrations of these isotopes are useful to evaluate several phenomena linked to the nitrogenous nutrition of plants [28]. Work with $\mathrm{N}$ fertilizers labeled with the ${ }^{15} \mathrm{~N}$ isotope showed that the fertilizer $\mathrm{N}$ utilization by the sugarcane plant was variable. However, according to [29], under 
Brazilian conditions, the ${ }^{15} \mathrm{~N}$ fertilizer recovery by sugarcane obtained in the cane plant cycle under field conditions is incipient. Therefore, it is important to evaluate the fertilizer $\mathrm{N}$ utilization by the cane plant, mainly because $\mathrm{N}$ fertilization in sugarcane is one of the issues still not clarified in the management of sugarcane plantations, and therefore, the use of ${ }^{15} \mathrm{~N}$-labeled $\mathrm{N}$ fertilizers would help in understanding this gap.

$\mathrm{N}$ presents complex dynamics, due to the multiple transformations and mobility in the soil-plant system that can result in losses to the plants. In this context, it is fundamental to develop adequate management of $\mathrm{N}$ fertilization, aiming at the best use of $\mathrm{N}$ by the sugarcane crop. Thus, starting from the hypothesis that the source and rates of $\mathrm{N}$ fertilization influence the $\mathrm{N}$ utilization by irrigated sugarcane in the Cerrado region, this study aimed to evaluate the stalk and crop residues (pointer and leaves) yield and the nitrogen use efficiency from sources and rates by irrigated sugarcane, in the cane plant cycle, using the ${ }^{15} \mathrm{~N}$ isotopic technique, in a very loamy dystrophic Red Latosol, Cerrado phase.

\section{Material and Methods}

The experiment was developed out under field conditions, during the 2014/2015 growing season, in an area at Rio Paraiso II Farm belonging to Raízen Plant, in the municipality of Jataí, GO. The geographical coordinates of the site are $17^{\circ} 44^{\prime} 2.62^{\prime \prime} \mathrm{S}$ and $51^{\circ} 39^{\prime} 6.06^{\prime \prime} \mathrm{W}$, with an average altitude of $907 \mathrm{~m}$. According to [30], the local climate is classified as Aw, tropical, with rainfall that occurs between the months of October to April and drought from May to September. The maximum temperature varies from 35 to $37^{\circ} \mathrm{C}$, and the minimum from varies 12 to $15^{\circ} \mathrm{C}$ (occurring up to $5{ }^{\circ} \mathrm{C}$ in winter). The annual precipitation reaches approximately $1800 \mathrm{~mm}$; however, it is poorly distributed throughout the year, according to the climatic data described in Figure 1.

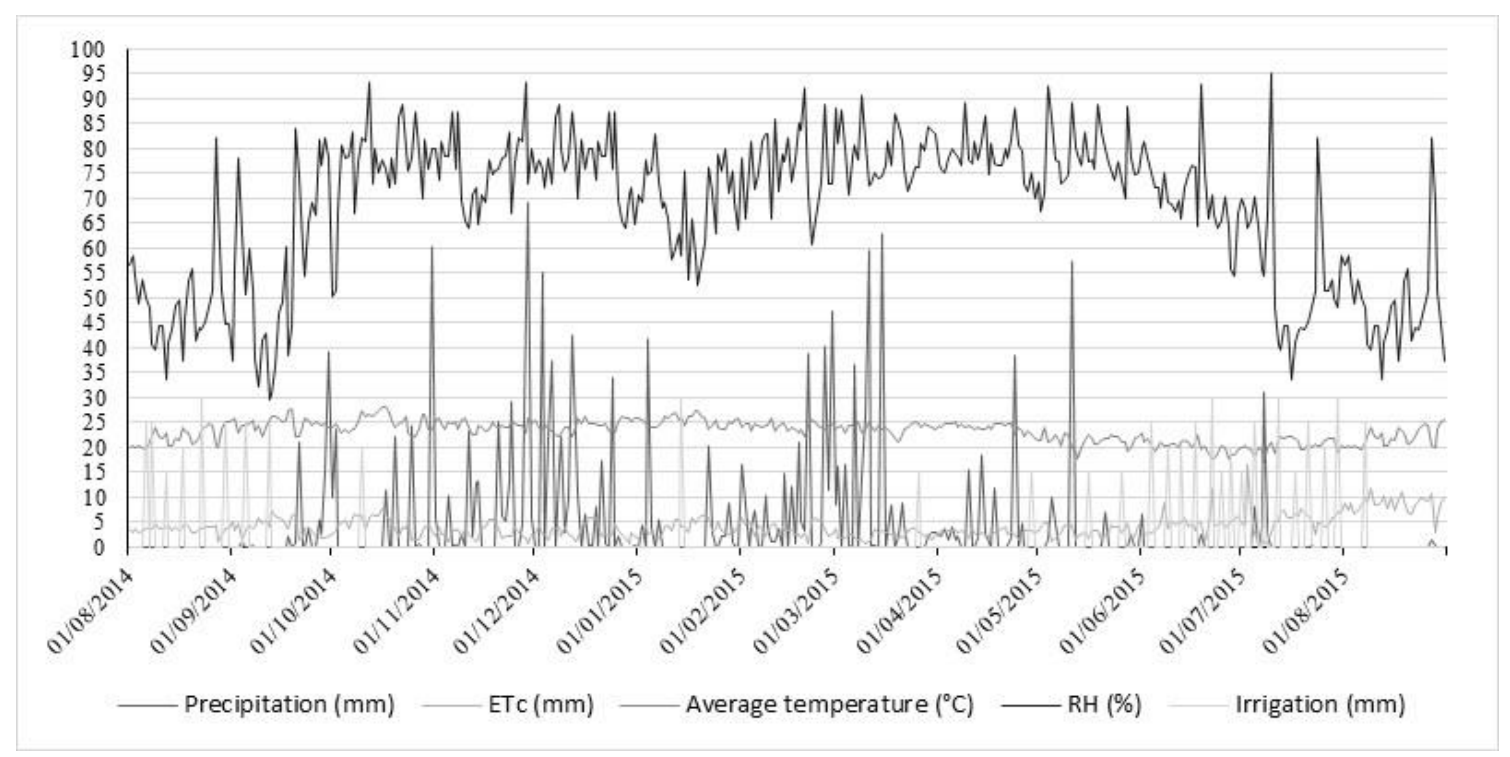

Figure 1. Daily water balance during the period of the experiment, Jataí-Goias harvest 2014/15. Source: INMET-National Institute of Meteorology Normal Station-Jataí-GO.

The experimental area has the soil classified as dystrophic Rhodic Haplustox soil [31] and dystroferric Red Latosol, very loamy, Cerrado (savannah) phase [32]. The area has a history of reforming the sugarcane plantation for seven years. The chemical, physical, water classification, granulometry, and texture of the samples were collected before the installation of the experiment, the descriptions of which are in Table 1. 
Table 1. Chemical, physical-water, granulometry, and soil textural classification of the experimental area, $0-0.10,0.10-0.20$, and $0.20-0.40 \mathrm{~m}$ depth.

\begin{tabular}{|c|c|c|c|c|c|c|c|c|}
\hline Layers & $\mathrm{pH}$ & O.M. & $P_{\text {Resin }}$ & $S$ & $\mathbf{K}$ & $\mathrm{Ca}$ & Mg & Al \\
\hline $\mathrm{m}$ & $\mathrm{CaCl}_{2}$ & $\mathrm{~g} \mathrm{dm}^{-3}$ & \multicolumn{2}{|c|}{$-\mathrm{mgdm}{ }^{-3}-$} & \multicolumn{4}{|c|}{$-\mathrm{mmol}_{\mathrm{C}} \mathrm{dm}^{-3}$} \\
\hline $0-0.10$ & 5.9 & 72 & 45 & 13 & 9.9 & 53 & 22 & $<1$ \\
\hline $0.10-0.20$ & 5.6 & 46 & 13 & 26 & 12.1 & 31 & 12 & $<1$ \\
\hline $0.20-0.40$ & 5.2 & 41 & 8 & 91 & 8.9 & 15 & 6 & $<1$ \\
\hline Layers & $\mathrm{H}+\mathrm{Al}$ & CEC & $\mathrm{V}$ & B & $\mathrm{Cu}$ & $\mathrm{Fe}$ & $\mathrm{Mn}$ & $\mathrm{Zn}$ \\
\hline $\mathrm{m}$ & \multicolumn{2}{|c|}{$\mathrm{mmol}_{\mathrm{C}} \mathrm{dm}^{-3}$} & $\%$ & \multicolumn{5}{|c|}{$\mathrm{mg} \mathrm{dm}^{-3}$} \\
\hline $0-0.10$ & 22 & 106.9 & 79 & 0.28 & 1.2 & 39 & 3.4 & 2.1 \\
\hline $0.10-0.20$ & 28 & 83.1 & 66 & 0.17 & 1.6 & 36 & 1.6 & 1.0 \\
\hline $0.20-0.40$ & 21 & 60.9 & 49 & 0.12 & 1.4 & 25 & 0.7 & 0.3 \\
\hline Layers & \multicolumn{3}{|c|}{ Granulometry $\left(\mathrm{g} \mathrm{kg}^{1}\right)$} & \multirow{2}{*}{\multicolumn{3}{|c|}{ Textural classification }} & $\theta_{\mathrm{CC}}$ & $\theta_{\mathrm{PMP}}$ \\
\hline $\mathrm{m}$ & Sand & Silt & Clay & & & & \multicolumn{2}{|c|}{$\mathrm{cm}^{3} \cdot \mathrm{cm}^{-3}$} \\
\hline $0-0.10$ & 96 & 82 & 822 & & Clayey & & \multirow{2}{*}{46.3} & \multirow{2}{*}{22.6} \\
\hline $0.10-0.20$ & 97 & 82 & 822 & & Clayey & & & \\
\hline $0.20-0.40$ & 85 & 71 & 845 & & Clayey & & 45.8 & 22.6 \\
\hline
\end{tabular}

$\mathrm{OM}-$ Organic matter; CEC —Cation exchange capacity; V—Bases saturation; $\theta \mathrm{CC}$-Water content in field capacity; $\theta \mathrm{PMP}-$ Water content at the permanent wilting point.

The experimental design used was in randomized blocks, with three replicates, analyzed in a $4 \times 2$ factorial scheme. The treatments consisted of four rates of fertilizer labeled with the ${ }^{15} \mathrm{~N}$ isotope in doses of 30,60,120, and $180 \mathrm{~kg} \mathrm{~N}$ ha $^{-1}$; and two $\mathrm{N}$ sources of fertilizer labeled with the ${ }^{15} \mathrm{~N}$ isotope (urea and ammonium nitrate).

At 60 days after planting, nitrogen fertilization was performed according to the treatments, applied to the haul, on the line side $(0.20 \mathrm{~m})$, contrary to the slope of the land. All treatments were fertilized at planting with phosphorus (100 $\mathrm{kg} \mathrm{ha}^{-1}$ of $\mathrm{P}_{2} \mathrm{O}_{5}$ : triple superphosphate), potassium $\left(80 \mathrm{~kg} \mathrm{ha}^{-1}\right.$ of $\mathrm{K}_{2} \mathrm{O}$ : potassium chloride), and micronutrients, according to the results from soil analysis and the recommendation of [33].

The urea and ammonium nitrate fertilizers were enriched, respectively, with 1.91 and $1.18 \%$ isotope ${ }^{15} \mathrm{~N}$ and applied in a $1.0 \mathrm{~m}$ microplot located centrally on the second line within the plots containing 6 lines of $5 \mathrm{~m}$, whose useful area were the 2.0 central lines of each plot, scoring $1.5 \mathrm{~m}$ at each end.

The system used for soil preparation was the conventional system, by means of plowing and harvesting, following the opening of the machining grooves. The variety used is the IACSP95-5000; the choice of this sugarcane variety was because it is being widely cultivated in soils similar to those in the present study, being a variety of a very high agricultural production, rusticity, precocity, indicated for a favorable environments for erect growing, excellent ratoon sprouting, good tillering and between rows covering, resistance to the main diseases, and not presenting tipping and flowering.

The use of pesticides, such as herbicides, insecticides, fungicides, and other products to control diseases, pests, and invasive plants, was carried out whenever necessary, as recommended.

The irrigation was carried out by means of a central pivot Zimmatic the irrigation management was carried out following the recommendations of the farmer. Meteorological data of maximum and minimum temperature $\left({ }^{\circ} \mathrm{C}\right)$, maximum and minimum relative humidity $(\%)$, wind speed $\left(\mathrm{m} \mathrm{s}^{-1}\right)$, solar radiation $\left(\mathrm{kJ} \mathrm{m}^{2}\right)$, and daily rainfall $(\mathrm{mm})$ were collected daily during the crop cycle through a meteorological station. After collecting these data, the water balance and the water balance in the soil were processed with the aid of the irrigation management software (IRRIGER ${ }^{\circledR}$ ). In the software, climate monitoring is used to calculate the daily water consumption of sugarcane, for the irrigation blade to be applied, at the relevant moment to irrigate. The software uses the Penman-Monteith method [34], 
which was adjusted for the estimation of evapotranspiration on a daily scale, with micrometeorological data of solar radiation, air temperature, wind speed, and relative humidity.

The sugarcane ${ }^{\circ}$ Brix was monitored in the field during the last four weeks antecedent to harvest. For the rational definition of the sugarcane harvest point, the parameter known as the Maturation Index (MI) was determined in the field using a portable refractometer. The MI values are: (a) less than 0.60 for green cane; (b) between 0.60 and 0.85 for cane in the process of maturation; (c) between 0.85 and 1 for mature cane; and (d) greater than 1 for cane in the process of sucrose decline [35].

Harvest was performed on August 25, 2015; stalk and pointer (sum between pseudo-Stockholm known as the 'palm heart' and emerging part known as the 'cartridge') yield was determined in $2 \mathrm{~m}$ of the two central lines, cutting as close as possible to the soil, followed by weighing in a hook-type digital scale.

The central plants of each line of the microplots were collected at the time of harvest, weighed, dried $\left(65^{\circ} \mathrm{C}\right.$ for $72 \mathrm{~h}$ ), and ground for the ${ }^{15} \mathrm{~N}$ and total $\mathrm{N}$ determination (Isotope Ratio Mass Spectrometry, IRMS) coupled to an automatic analyzer 20-20 ANCA-SL, Europe Scientific, Crewe, according to the methodology described by [36].

The total accumulated $\mathrm{N}(\mathrm{AN}), \mathrm{N}$ in the plant derived from the fertilizer in percentage and in quantity (Npdff), nitrogen fertilizer use efficiency (NUE, \%) and the amount of $\mathrm{N}$ in sugarcane derived from soil (Npdfs) were calculated according to [37], using the following sequence of procedures.

(a) Accumulated nitrogen stalk and pointer dry mater-DM $\left(\mathrm{AN}, \mathrm{kg} \mathrm{ha}^{-1}\right)$ :

$$
\mathrm{AN}=(\mathrm{N} \times \mathrm{DM}) \div 1000
$$

where $\mathrm{N}$ is the nitrogen content $\left(\mathrm{g} \mathrm{kg}^{-1}\right)$ stalk and pointer, and DM is the total dry matter $\left(\mathrm{kg} \mathrm{ha}^{-1}\right)$.

(b) Percentage of nitrogen in stalk and pointer derived from fertilizer (\%Npdff) were obtained, using Equation (2), obtained by the principle of isotopic dilution [37] :

$\% \mathrm{Npdff}=\left(\%\right.$ of $\mathrm{N}^{15}$ atoms in excess in the plant $\div \%$ of $\mathrm{N}^{15}$ atoms in excess in the fertilizer $) \times 100$

where the percentage of ${ }^{15} \mathrm{~N}$ atoms in excess in the plant is the percentage of ${ }^{15} \mathrm{~N}$ atoms in the plant subtracting natural abundance ${ }^{15} \mathrm{~N}(0.3663 \%)$, and the percentage of ${ }^{15} \mathrm{~N}$ atoms in excess in the fertilizer is the percentage of ${ }^{15} \mathrm{~N}$ atoms in the fertilizer subtracting natural abundance ${ }^{15} \mathrm{~N}(0.3663 \%)$.

(c) Amount of $\mathrm{N}$ in stalk and pointer derived from fertilizer (Ndff, $\mathrm{kg} \mathrm{ha}^{-1}$ )

$$
\mathrm{Ndff}=(\% \mathrm{Ndff} \times \mathrm{AN}) \div 100
$$

where $\mathrm{AN}$ is the accumulated nitrogen $\left(\mathrm{kg} \mathrm{ha}^{-1}\right)$ and $\% \mathrm{Npdff}$ is the percentage of $\mathrm{N}$ in the plant derived from fertilizer.

(d) Amount of N stalk and pointer derived from soil and of the other sources (sol native N, biological nitrogen fixation, remaining crop residues, rainfall, and others) ( $\mathrm{Ndfs}, \mathrm{kg} \mathrm{ha}^{-1}$ ):

$$
\mathrm{Ndfs}=\mathrm{AN}-\mathrm{Ndff}
$$

where $\mathrm{AN}=$ accumulated nitrogen $\left(\mathrm{kg} \mathrm{ha}^{-1}\right)$ and $\mathrm{Ndff}$ is the amount of $\mathrm{N}$ in the straw or grains derived from fertilizer.

(e) Nitrogen fertilizer use efficiency (NUE, \%) in stalk and pointer refers to the $\mathrm{N}$ recovery derived from $\mathrm{N}$ applied as fertilizer (ammonium nitrate or urea- ${ }^{15} \mathrm{~N}$ ):

$$
\mathrm{NUE}=(\mathrm{Ndff} \div \mathrm{ANA}) \times 100
$$

where Ndff is the amount of nitrogen in the stalk and pointer derived from the fertilizer $\left(\mathrm{kg} \mathrm{ha}^{-1}\right)$ and ANA is the amount of nitrogen applied as labeled fertilizer $\left(\mathrm{kg} \mathrm{ha}^{-1}\right)$. 
The data obtained were analyzed statistically by variance analysis and when significant effects were detected ( $F$ test $5 \%$ of probability), they were adjusted to regression equations. Linear and quadratic components were tested, and then we established the model with a larger significant degree. The means for $\mathrm{N}$ source (ammonium nitrate and urea) were compared by the Tukey test to $5 \%$ of probability. The statistical analyses were carried out using the SAS package 8.02 [38].

\section{Results and Discussion}

In the growing season of 2014/15, the rainfall precipitation at the experiment site was $1701.40 \mathrm{~mm}$ as shown in Figure 1, which is a close enough value for the development of sugarcane, which varies from 1500 to $2500 \mathrm{~mm}$, according to [39]. However, precipitation did not occur regularly throughout the harvest, predominating in the months of 10/2014 to 06/2015. Therefore, the following two months after planting, $08 / 2014$ to $10 / 2014$ and at the end of the growth phase $06 / 2015$ to $08 / 2015$, the rainfall was insufficient, needing irrigation $(650.0 \mathrm{~mm}$, total volume of $2351.40 \mathrm{~mm}$ during the growing cycle).

In the analysis of variance, there was a significant effect on the interaction between the source and $\mathrm{N}$ dose factors for the variable $\mathrm{N}$ accumulated by the sugarcane plant (NA, $\mathrm{kg} \mathrm{ha}^{-1}$ ), percentage of $\%$ Npdff, amount of Npdff $\left(\mathrm{kg} \mathrm{ha}^{-1}\right), \mathrm{NUE} \%$, and Npdfs. It also showed that the effect of fertilizer $\mathrm{N}$ source was dependent on the $\mathrm{N}$ rate.

Unfolding the rate factor for each fertilizer $\mathrm{N}$ source, for the variable accumulated nitrogen (NA) in the stalk, it is observed that there was an accumulation of 470.67 and $451.98 \mathrm{~kg} \mathrm{~N} \mathrm{ha}^{-1}$, respectively, with the rates of 118.49 and $138.25 \mathrm{~kg} \mathrm{ha}^{-1}$ of $\mathrm{N}$, which corresponded to increases of up to $69.91 \%$ and $53.41 \%$ for ammonium nitrate and urea, respectively, compared to the control treatment without $\mathrm{N}$ application (Figure 2A).

The amount of nitrogen accumulated in the pointer was 374.52 and $397.69 \mathrm{~kg} \mathrm{~N} \mathrm{ha}^{-1}$, for N rates of 119.08 and $126.0 \mathrm{~kg} \mathrm{ha}^{-1}$, corresponding to increases of up to $70.14 \%$ and $56.98 \%$, respectively, for ammonium nitrate and urea (Figure 2B). There was a higher accumulation of $\mathrm{N}$ in the sugarcane stalk in relation to the pointer, and the ammonium nitrate contributed most of this accumulation in the stalk in relation to the urea. This is different from what occurred in the pointer, as the urea source contributed to greater $\mathrm{N}$ accumulation. The $\mathrm{N}$ exported in the stalk represented about $54.44 \%$ ( $461.32 \mathrm{~kg} \mathrm{ha}^{-1}$ ) of the accumulated in the biomass of the shoot, whose value is close to the $56 \%$ found by [40] for varieties RB867515, RB92579, and RB863129, and 50\% obtained by [29] for the variety SP31-3250. This is an important behavior, since the residue or remaining straw in the field is composed of leaves and pointer, and in the present study, it accumulated almost $45.50 \%$ of the $\mathrm{N}$ of the shoot.

The decomposition of leaf and pointer residues returned to the soil can provide $\mathrm{N}$ for the plants through a slow and dependent process of the involved factors $[6,27,41]$, since the mineralization of the organic $\mathrm{N}$ is mediated by the quimio-organo-trophic microorganism (heterotrophic), which in turn is dependent on climatic factors, especially moisture and temperature [5].

Unfolding the rate factor, for each $\mathrm{N}$ source, for the variable \% Npdff in the stalk, increases by $14.61 \%$ and $12.69 \%$, respectively, were observed for ammonium nitrate and urea (Figure 2C). In the pointer, increases of $6.78 \%$ and $6.15 \%$ were observed respectively for ammonium nitrate and urea (Figure 2D). These results show that there was a greater favoring of the stalk, the smallest part of the $\mathrm{N}$ in the plant comes from the fertilizer, and the ammonium nitrate source contributed to a higher percentage of $\mathrm{N}$ in the plant. 

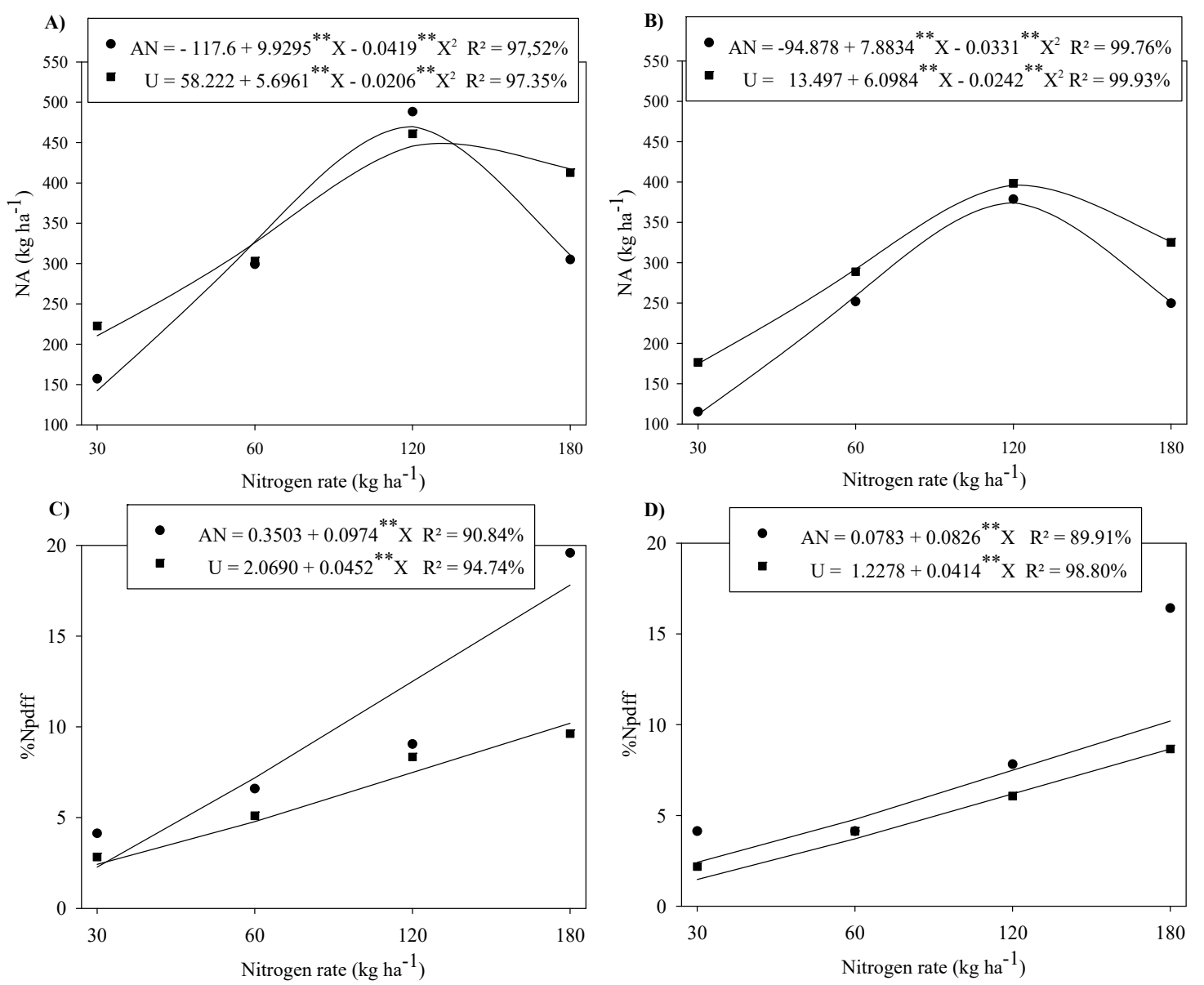

Figure 2. Accumulated nitrogen (NA) and percentage of $\mathrm{N}$ in sugarcane plant derived from fertilizer (\%Npdff), stalk (A,C), and pointer (B,D), in the cane plant cycle, as affected by $\mathrm{N}$ rate as ammonium nitrate $(\mathrm{AN})$ and urea $(\mathrm{U}) .{ }^{* *}$ Significant respectively at $1 \%$ probability according to test $\mathrm{F}$.

Unfolding the source factor for each rate of $\mathrm{N}$ fertilizer and for the variable \% Npdff in the stalk, it is observed that there was a greater value from ammonium nitrate at the rate of 30,60, and $180 \mathrm{~kg} \mathrm{~N}$ $\mathrm{ha}^{-1}$, corresponding to increases of up to $1.31 \%, 1.50 \%$, and $9.87 \%$ in relation to urea. In the pointer, it was observed that there was a higher percentage with ammonium nitrate use at the rate of 30, 120, and $180 \mathrm{~kg} \mathrm{ha}^{-1}$ of $\mathrm{N}$, corresponding to increases of up to $1.96 \%, 1.76 \%$, and $7.77 \%$ in relation to urea (Table 2). These results show that under low or high $\mathrm{N}$ fertilization rates, the ammonium nitrate contributed to a higher percentage of $\mathrm{N}$ in the sugarcane plant from the fertilizer, which was probably due to its lower loss in the production environment.

In the unfolding of the source factor, for each fertilizer $\mathrm{N}$ rate, for the variable accumulated $\mathrm{N}$ (AN) in the stalk, there was a higher accumulation of $\mathrm{N}$, with the application of 30 and $180 \mathrm{~kg} \mathrm{ha}^{-1}$ of $\mathrm{N}$, in the form of urea, corresponding to increases of $29.35 \%$ and $26.11 \%$, respectively, in relation to the ammonium nitrate (Table 2). 
Table 2. Nitrogen accumulated (NA) and percentage of $\mathrm{N}$ in sugarcane plant derived from fertilizer (\%Npdff), by sugarcane plant (stalk and pointer), in the cane plant cycle, as affected by $\mathrm{N}$ rate as ammonium nitrate and urea.

\begin{tabular}{|c|c|c|c|c|}
\hline \multirow{2}{*}{ N Source } & \multicolumn{4}{|c|}{ NA (kg ha $\left.{ }^{-1}\right)$} \\
\hline & $30 \mathrm{~kg} \mathrm{ha}^{-1}$ & $60 \mathrm{~kg} \mathrm{ha}^{-1}$ & $120 \mathrm{~kg} \mathrm{ha}^{-1}$ & $180 \mathrm{~kg} \mathrm{ha}^{-1}$ \\
\hline & \multicolumn{4}{|c|}{ Stalk } \\
\hline Urea & $222.75 \mathrm{a}$ & 299.32 & 460.86 & 412.78 a \\
\hline \multirow[t]{2}{*}{ Ammonium nitrate } & $157.38 \mathrm{~b}$ & 303.19 & 488.44 & $305.00 \mathrm{~b}$ \\
\hline & \multicolumn{4}{|c|}{ Pointer } \\
\hline Urea & $176.38 \mathrm{a}$ & 288.86 & 398.43 & $325.17 \mathrm{a}$ \\
\hline \multirow[t]{3}{*}{ Ammonium nitrate } & $115.49 \mathrm{~b}$ & 252.03 & 378.86 & $249.83 \mathrm{~b}$ \\
\hline & \multicolumn{4}{|c|}{$\%$ Npdff } \\
\hline & \multicolumn{4}{|c|}{ Stalk } \\
\hline Urea & $2.83 \mathrm{~b}$ & $5.10 \mathrm{~b}$ & 8.34 & $9.63 \mathrm{~b}$ \\
\hline Ammonium nitrate & $4.14 \mathrm{a}$ & $6.60 \mathrm{a}$ & 9.06 & $19.50 \mathrm{a}$ \\
\hline & \multicolumn{4}{|c|}{ Pointer } \\
\hline Urea & $2.18 \mathrm{~b}$ & $4.13 \mathrm{a}$ & $6.07 \mathrm{~b}$ & $8.66 \mathrm{~b}$ \\
\hline Ammonium nitrate & $4.14 \mathrm{a}$ & $4.14 \mathrm{a}$ & $7.83 \mathrm{a}$ & $16.43 \mathrm{a}$ \\
\hline
\end{tabular}

Regarding the $\mathrm{N}$ accumulated in the pointer, it was observed that there was a greater accumulation with urea, at rates of 30 and $180 \mathrm{~kg} \mathrm{Nha}^{-1}$, corresponding to increases of $34.52 \%$ and $23.17 \%$, respectively, in relation to ammonium nitrate. These results show that under conditions of low or high nitrogen content, urea contributed to higher $\mathrm{N}$ accumulation. This finding can be explained by the high $\mathrm{N}$ concentration in urea when compared to ammonium nitrate, in addition to its greater availability in a short space of time, making it different from medium rates such as 60 and $120 \mathrm{~kg} \mathrm{ha}^{-1}$, which had no significant effect. According to [42], the plants are able to assimilate the inorganic forms of $\mathrm{N} \mathrm{NH}_{4}{ }^{+}$, and $\mathrm{NO}_{3}{ }^{-}$absorbed from the soil and also obtain the $\mathrm{N}$ by symbiotic relations with bacteria from the molecular $\mathrm{N}\left(\mathrm{N}_{2}\right)$ and assimilate the ammonia, but the plant growth becomes favored when there is the reach of the two forms of $\mathrm{N}, \mathrm{NH}_{4}{ }^{+}$, and $\mathrm{NO}_{3}{ }^{-}$, because when they are assimilated, they trigger a beneficial ionic balance inside the plant. However, some plant species have a preference for the ammoniacal form of $\mathrm{N}$ rather than nitrate $[43,44]$.

For each source of $\mathrm{N}$ fertilizer applied, for the variable amount of nitrogen in the plant derived from native $\mathrm{N}$ of the soil (Npdfs) in the stalk, it is observed that the Npdfs was 428.03 and $414.31 \mathrm{~kg} \mathrm{~N} \mathrm{ha}^{-1}$ at the rates of 114.43 and $135.54 \mathrm{~kg} \mathrm{~N} \mathrm{ha}^{-1}$, corresponding to increases of up to $68.12 \%$ and $50.28 \%$, respectively, for ammonium nitrate and urea (Figure 3A). In the pointer, it is observed that the Npdfs was 346.16 and $373.75 \mathrm{~kg} \mathrm{~N} \mathrm{ha}^{-1}$ in the doses of 115.19 and $123.25 \mathrm{~kg} \mathrm{~N} \mathrm{ha}^{-1}$, corresponding to increases of up to $68.77 \%$ and $54.13 \%$, respectively, for ammonium nitrate and urea (Figure 3B). These results show that of the amount of $\mathrm{N}$ accumulated by sugarcane, there was a smaller contribution of $\mathrm{N}$ from the fertilizer when compared to $\mathrm{N}$ derived from the native $\mathrm{N}$ soil. These results are in agreement with studies carried out by $[6,45,46]$, which show that the contribution of $N$ from the fertilizer to the cane plant crop can be small compared to the total $\mathrm{N}$ absorbed by the plant. Ref. [7] considered that sugarcane absorbs most of the $\mathrm{N}$ of mineralized organic $\mathrm{N}$ of the soil.

For the Npdff in the stalk, we observed that the \%Npdff was of 61.96 and $42.26 \mathrm{~kg} \mathrm{~N} \mathrm{ha}^{-1}$ at the dose of $180 \mathrm{~kg} \mathrm{~N} \mathrm{ha}^{-1}$, corresponding to increases of $86.34 \%$ and $89.34 \%$, respectively, for ammonium nitrate and urea (Figure 3C). While in the pointer, we observed that the \%Npdff was of 44.40 and $30.45 \mathrm{~kg} \mathrm{~N} \mathrm{ha}^{-1}$ at the rate of $180 \mathrm{~kg} \mathrm{~N} \mathrm{ha}^{-1}$, corresponding to increases of up to $79.97 \%$ and $80.15 \%$, respectively, for ammonium nitrate and urea (Figure 3D). These results show that there was a greater accumulation of $\mathrm{N}$ derived from fertilizer in the stalk of the sugarcane as compared to the pointer. In addition, the ammonium nitrate contributed most of the \%Npdff in the stem compared to the urea, 
which is different from what occurred in the pointer, the urea source contributing to a greater amount of nitrogen.

For NUE by the stalk, it is observed that the NUE was $38.80 \%$ and $23.59 \%$ for the rate of 127.08 and $110.20 \mathrm{~kg} \mathrm{~N} \mathrm{ha}^{-1}$, corresponding to increases of $16.02 \%$ and $7.72 \%$, respectively, for ammonium nitrate and urea (Figure 3E). For the pointer, the NUE was $21.37 \%$ and $21.36 \%$ for the rate of 140.71 and $110.16 \mathrm{~kg} \mathrm{~N} \mathrm{ha}^{-1}$, corresponding to increases of $8.58 \%$ and $7.71 \%$, respectively, for ammonium nitrate and urea (Figure $3 \mathrm{~F}$ ).
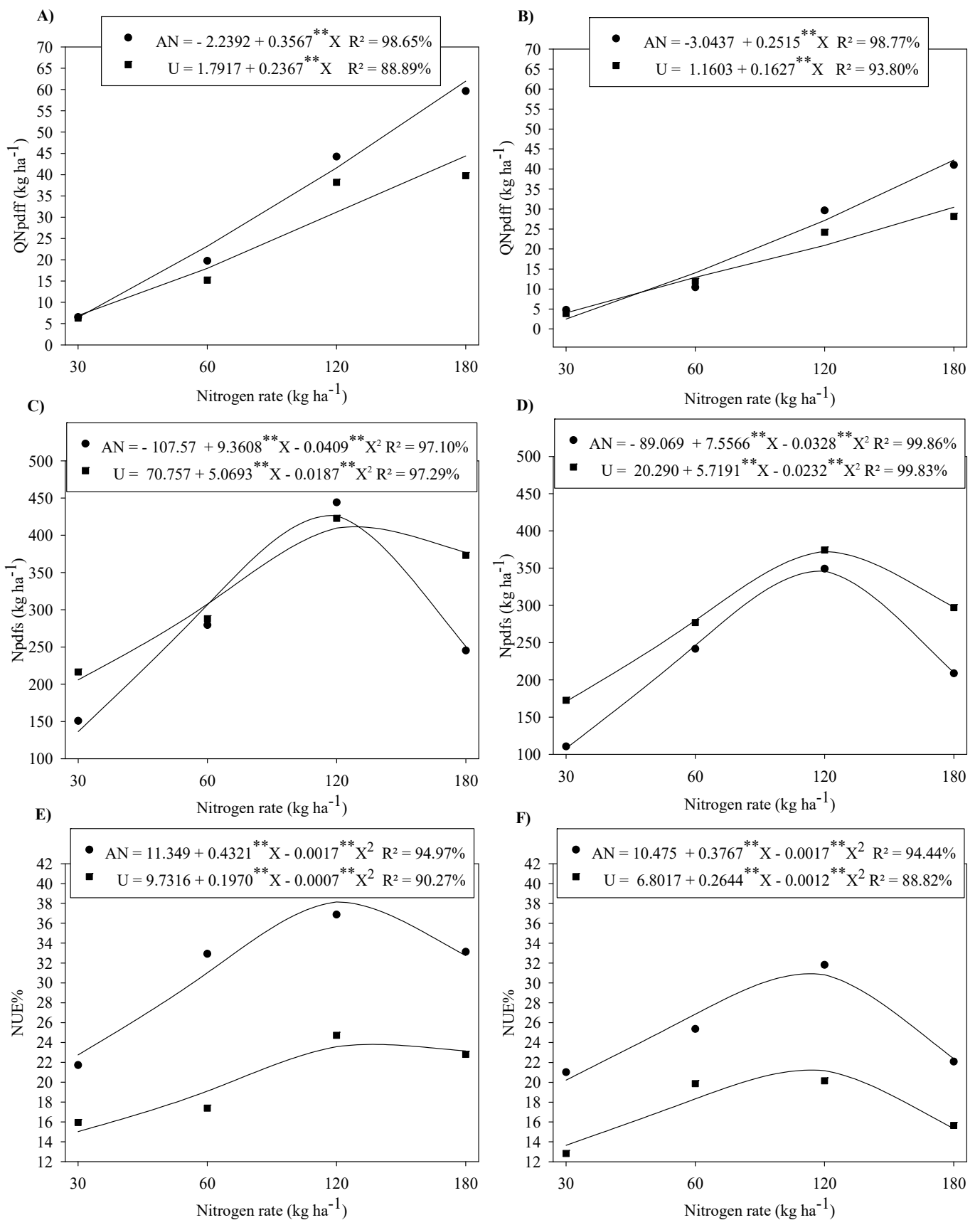

Figure 3. Amount of nitrogen in sugarcane plant derived from fertilizer ( $\mathrm{Npdff}, \mathrm{kg} \mathrm{ha}^{-1}$ ), amount of $\mathrm{N}$ in sugarcane plant derived from soil (Npdfs, $\mathrm{kg} \mathrm{ha}^{-1}$ ) and nitrogen use efficiency (NUE) by sugarcane plant, stalk $(\mathbf{A}, \mathbf{C}, \mathbf{E})$, and pointer $(\mathbf{B}, \mathbf{D}, \mathbf{F})$, in the cane plant cycle, as affected by $\mathrm{N}$ rate as ammonium nitrate $(\mathrm{AN})$ and urea $(\mathrm{U}) .{ }^{* *}$ Significant respectively at $1 \%$ probability according to test $\mathrm{F}$. 
These results show that there was greater favoring of the stalk and that the smallest part of the $\mathrm{N}$ in the plant comes from the fertilizer, and the ammonium nitrate source contributed to a higher percentage of $\mathrm{N}$ utilization by the plant. The results found by [29] show that the $\mathrm{N}$ distribution of the fertilizer in the different parts of the sugarcane plant did not vary with $\mathrm{N}$ rates, being on average $50 \%$ in stalks, $22 \%$ in dry leaves, $20 \%$ in pointers, and $8 \%$ in roots. The mean NUE from fertilizer was $21 \%$, with no significant difference between varieties. This recovery was lower than the $55 \%$ obtained by [19], $31 \%$ by [47], and about $30 \%$ by [29], and it was within the range of $15 \%$ to $42 \%$ observed by [23] in different varieties. The higher $\mathrm{N}$ utilization can be explained by the higher soil moisture in the irrigated system, which possibly allowed the reduction of $\mathrm{N}$ losses due to the volatilization of ammonia, in addition to the higher amount of fertilizer applied. The lower recovery can be the result [27] of losses due to the volatilization of $\mathrm{NH}_{3}$, which may reach up to $46 \%$ [19] or by leaching after the rainfalls have started [27]. Most of the residual ${ }^{15} \mathrm{~N}$ remains in the soil as organic $\mathrm{N}$ due to immobilization and will be released slowly by remineralization $[47,48]$. While inorganic fertilizer $\mathrm{N}$ provides an immediate source of mineral $\mathrm{N}$ for the crop, most of the $\mathrm{N}$ in the crop is often derived from the $\mathrm{N}$ that is stored in the soil.

The results found in the literature are lower than those observed in this study, which show the average proportion of $\mathrm{N}$ in the plant derived from the fertilizer-for example, $22 \mathrm{~kg} \mathrm{ha}^{-1}$ observed by [29] and $24.7 \mathrm{~kg} \mathrm{ha}^{-1}$ observed by [47]. There are still others that observed small contributions of the total $\mathrm{N}$ absorbed in cane plant from the fertilizer [6,49].

Regarding the $\mathrm{N}$ rate of the variable amount of Npdff in the stalk, it is observed that there was a higher Npdff with the ammonium nitrate, in the rates of 120 and $180 \mathrm{~kg} \mathrm{ha}^{-1} \mathrm{of} \mathrm{N}$, corresponding to increases of $13.65 \%$ and $33.36 \%$ in relation to urea. However, in the pointer, it was observed that there was a higher amount of $\mathrm{N}$ from urea at the same rates, corresponding to increases of up to $18.47 \%$ and $31.38 \%$ in relation to the use of ammonium nitrate (Table 3). These results show that under high $\mathrm{N}$ conditions, ammonium nitrate contributed to a higher amount of $\mathrm{N}$ in the plant, which can be explained by the fact that ammonium nitrate is more available for plant absorption, although it is more propitious to losses in the system. The levels of $\mathrm{NH}_{4}{ }^{+}$and $\mathrm{NO}_{3}{ }^{-}$found in the soil come from a series of factors, such as environmental conditions (precipitation and temperature) and the balance between mineralization and immobilization processes resulting from biological activity [50]. $\mathrm{NH}_{4}{ }^{+}$, a cation, in the soil remains adsorbed on the surfaces of inorganic or organic particles that exhibit negative charges. This form of $\mathrm{N}$ remaining adsorbed to the particles naturally represents a reserve in the soil, being protected and at the same time available to plants and macrobiotas. $\mathrm{The}^{\mathrm{NO}_{3}}{ }^{-}$as an anion is kept dissolved in solution being repelled by the soil particles, thus being more vulnerable to losses, such as leaching [42].

The use of the ${ }^{15} \mathrm{~N}$ isotopic tracer technique to measure the $\mathrm{N}$-fertilizer absorption by the plant has reported a low recovery of $\mathrm{N}$ by sugarcane derived from mineral fertilizers. According to [51], during the early stages of sugarcane, $\mathrm{N}$ fertilizer is the main source of the nutrient to the crop, which represents more than $70 \%$ of the $\mathrm{N}$ extracted by the plants. However, sugarcane is a semi-perennial crop, remaining in the field for at least 12 months. The recovery of fertilizer $\mathrm{N}$ decreases over the course of the cycle and, at the time of harvesting, reaches values ranging from $5 \%$ to $42 \%$ [23,51,52]. However, for [53] and [54] in the sugarcane harvest, $\mathrm{N}$ fertilizer participation in the total $\mathrm{N}$ of the plant is significantly reduced, and in many studies, there is no response to $\mathrm{N}$ fertilization.

Unfolding the source factor, for each $\mathrm{N}$ fertilization rate, for the variable fertilizer $\mathrm{N}$ utilization (NUE) for the stem, it was observed that the $\mathrm{N}$ of the ammonium nitrate was used at the rates of 60, 120, and $180 \mathrm{~kg} \mathrm{~N} \mathrm{ha}^{-1}$, corresponding to yields of up to $7.55 \%, 5.04 \%$, and $11.05 \%$ relative to urea. As for the pointer, it was observed that $\mathrm{N}$ increased the ammonia nitrate at the rates of 30,120, and $180 \mathrm{~kg}$ $\mathrm{N} \mathrm{ha}^{-1}$, corresponding to $3.11 \%, 4.56 \%$, and $7.15 \%$ in relation to urea (Table 3). These results show that the $\mathrm{N}$ utilization from the ammonium nitrate source was higher in both the shoot and the pointer. This result can be explained by the higher contribution of the percentage of nitrogen in the cane plant from the fertilizer (\% Npdff) (Table 3) and $\mathrm{N}$ recovery in the plant from the fertilizer (NUE) (Table 3). 
For each fertilizer $\mathrm{N}$ rate, for the variable amount of Npdfs in the stalk, it is observed that there were higher Npdfs using urea, when applying 30 and $180 \mathrm{~kg} \mathrm{~N}$ ha $^{-1}$ corresponding to uses of up to $30.30 \%$ and $34.22 \%$ in relation to ammonium nitrate. In the pointers, there also were higher Npdfs with urea at the rates of 30 and $180 \mathrm{~kg} \mathrm{~N} \mathrm{ha}^{-1}$, corresponding to uses of up to $35.83 \%$ and $29.70 \%$ in relation to ammonium nitrate (Table 3).

Table 3. Amount of $\mathrm{N}$ in sugarcane plant derived from fertilizer ( $\mathrm{Npdff}, \mathrm{kg} \mathrm{ha}^{-1}$ ), amount of $\mathrm{N}$ in sugarcane plant derived from soil (Npdfs), and nitrogen use efficiency (NUE), by sugarcane plant (stalk and pointer), in the cane plant cycle, as affected by $\mathrm{N}$ rate as ammonium nitrate and urea.

\begin{tabular}{|c|c|c|c|c|}
\hline \multirow{2}{*}{ N Source } & \multicolumn{4}{|c|}{ Npdff (kg ha $\left.{ }^{-1}\right)$} \\
\hline & $30 \mathrm{~kg} \mathrm{ha}^{-1}$ & $60 \mathrm{~kg} \mathrm{ha}^{-1}$ & $120 \mathrm{~kg} \mathrm{ha}^{-1}$ & $180 \mathrm{~kg} \mathrm{ha}^{-1}$ \\
\hline & \multicolumn{4}{|c|}{ Stalk } \\
\hline Urea & 6.30 & $15.22 \mathrm{a}$ & $38.20 \mathrm{~b}$ & $39.74 b$ \\
\hline \multirow[t]{2}{*}{ Ammonium nitrate } & 6.52 & $19.75 \mathrm{a}$ & $44.24 \mathrm{a}$ & $59.64 \mathrm{a}$ \\
\hline & \multicolumn{4}{|c|}{ Pointer } \\
\hline Urea & 3.85 & 10.44 & $24.18 \mathrm{~b}$ & $28.16 \mathrm{~b}$ \\
\hline \multirow[t]{3}{*}{ Ammonium nitrate } & 4.78 & 11.92 & $29.66 \mathrm{a}$ & $41.04 \mathrm{a}$ \\
\hline & \multicolumn{4}{|c|}{ Npdfs $\left(\mathrm{kg} \mathrm{ha}^{-1}\right)$} \\
\hline & \multicolumn{4}{|c|}{ Stalk } \\
\hline Urea & $216.44 \mathrm{a}$ & 287.97 & 422.67 & $373.03 \mathrm{a}$ \\
\hline \multirow[t]{2}{*}{ Ammonium nitrate } & $150.86 \mathrm{~b}$ & 279.57 & 429.66 & $245.36 \mathrm{~b}$ \\
\hline & \multicolumn{4}{|c|}{ Pointer } \\
\hline Urea & $172.53 \mathrm{a}$ & $241.59 \mathrm{a}$ & 349.20 & $297.01 \mathrm{a}$ \\
\hline \multirow[t]{2}{*}{ Ammonium nitrate } & $110.70 \mathrm{~b}$ & $276.94 \mathrm{a}$ & 374.25 & $208.77 \mathrm{~b}$ \\
\hline & \multicolumn{4}{|c|}{ NUE $(\%)$} \\
\hline & \multicolumn{4}{|c|}{ Stalk } \\
\hline Urea & 21.02 & $25.37 \mathrm{~b}$ & $31.83 \mathrm{~b}$ & $22.08 \mathrm{~b}$ \\
\hline \multirow[t]{2}{*}{ Ammonium nitrate } & 21.72 & $32.92 \mathrm{a}$ & $36.87 \mathrm{a}$ & $33.13 \mathrm{a}$ \\
\hline & \multicolumn{4}{|c|}{ Pointer } \\
\hline Urea & $12.83 \mathrm{~b}$ & 17.39 & $20.15 \mathrm{~b}$ & $15.65 \mathrm{~b}$ \\
\hline Ammonium nitrate & $15.94 \mathrm{a}$ & 19.86 & $24.71 \mathrm{a}$ & $22.80 \mathrm{a}$ \\
\hline
\end{tabular}

The results found by [29] show that the recovery of ${ }^{15} \mathrm{~N}$-urea by the cane plant (whole plant) was in the average of the experiments of $30 \%, 30 \%$, and $21 \%$, respectively, for the doses and 40,80 , and $120 \mathrm{~kg} \mathrm{ha}^{-1}$ of $\mathrm{N}$ and the lowest $\mathrm{N}$-urea recovery at the highest doses, at $120 \mathrm{~kg} \mathrm{ha}^{-1}$, was due to the $\mathrm{N}$ losses of the soil-plant system. Ref. [19] in the balance of ${ }^{15} \mathrm{~N}$ fertilizer obtained recovery in the soil-plant system of ammonium sulfate and urea of $74 \%$ and $55 \%$ on average, respectively. The distribution of roots, moisture content, plant development rate, $\mathrm{NH}_{4}{ }^{+}$, and $\mathrm{NO}_{3}{ }^{-}$content in solution in the soil are the factors that influence $\mathrm{N}$-mineral utilization by plants [43].

These results show that where the urea source was used, the contribution of the $\mathrm{N}$ derived from soil was higher. In addition, the sugarcane has a preference for the $\mathrm{NH}_{4}{ }^{+}$form [44], which may present higher yield of stalks when preferentially nourished by this form of $\mathrm{N}$. This fact indicates the possibility of changes in the forms of management of the sugarcane plantations, aiming to make the $\mathrm{N}$ available to the crop in reduced form (ammoniacal). However, more detailed studies on this subject are still needed for their substantiation. The results of the present study demonstrate that regardless of the rate and $\mathrm{N}$ source, the soil was the main source of $\mathrm{N}$ for sugarcane, which demonstrates the need for management practices that maintain the residual $\mathrm{N}$ from fertilization, as well as the mineralized $\mathrm{N}$ of the crop residues, within the zone explored by the roots system of the subsequent ratoon/cycles, which is associated with management practices that maintain the potential of soil $\mathrm{N}$ supply in the short term. It is worth mentioning that the increment of the $\mathrm{N}$ rate, independently of the source, provided an increase in the yield of shoots and pointers. 
$\mathrm{N}$ is an element that presents a complex biogeochemical cycle because it is naturally found in the environment in a large diversity of chemical compounds, and it presents multiple transformations that occur in the soil-plant-atmosphere system. $\mathrm{N}$ cycling in the soil is characterized by a series of chemical and microbial reactions, which may result in the low $\mathrm{N}$ efficiency of nitrogen fertilizers, especially in situations where liquid $\mathrm{N}$ mineralization is high [55]. In addition, there is a biological nitrogen fixation (BNF) contribution to sugarcane. Ref. [56] mentions that the average Brazilian contribution of BNF for sugarcane nutrition would be $40 \mathrm{~kg} \mathrm{~N} \mathrm{ha}^{-1}$, averaging $20 \%$ of the $\mathrm{N}$ assimilated by the plant. Ref. [57], evaluating six commercial sugarcane varieties, observed that they were able to obtain the BNF from 40.2 to $64.0 \mathrm{~kg} \mathrm{~N} \mathrm{ha}^{-1}$.

The organic $\mathrm{N}$ complexes in soil organic matter can represent some $95 \%$ of the total $\mathrm{N}$ of the soil; therefore, it is natural that the availability of the element to the plants is low [5]. Nucleic acids, nitrogenous bases, proteins, peptides, urea, chitin, and chytobiose peptidoglycan are examples of known forms of organic $\mathrm{N}$ found in nature. However, much of the organic $\mathrm{N}$ is in complex forms, many of them unknown, being only a small part of this mineralized material. Of the total organic $\mathrm{N}$ found in the soils, only $2 \%$ to $5 \%$ are mineralized per year, but according to the type of soil, this value may represent enough in the supply demanded by the agricultural crops [50]. Several authors have shown that the main source of $\mathrm{N}$ to the crops is derived from the soil organic matter through the process of mineralization $[46,51,58]$. Thus, studies in agricultural soils can help to uncover the paths covered by the $\mathrm{N}$, avoiding losses and ensuring a more adequate management of the nutrient in the agrosystems.

The values of stalk dry matter (DMS), pointer dry matter (DMP), stalk productivity (SP), and pointer productivity (PP) observed in this study show a behavior similar to $\mathrm{N}$ accumulation and utilization (Figure 4).

For the DMS as affected by the $\mathrm{N}$ rate, it was observed that there was an estimated maximum quadratic increment of 102.34 and $108.12 \mathrm{t} \mathrm{ha}^{-1}$ with 119.11 and $173.64 \mathrm{~N} \mathrm{~kg} \mathrm{ha}^{-1}$, corresponding to increases of 26.4 and $28.88 \mathrm{t} \mathrm{ha}^{-1}(25.44 \%$ and $26.71 \%)$, in relation to control treatment, respectively, for ammonium nitrate and urea (Figure 4A). As for rate-dependent DMP, there was an estimated maximum quadratic increase of 34.56 and $33.13 \mathrm{tha}^{-1}$ with 122.73 and $143.36 \mathrm{~kg} \mathrm{ha}^{-1}$ of $\mathrm{N}$, corresponding to increases of 12.90 and $14.13 \mathrm{tha}^{-1}(37.32 \%$ and $42.65 \%)$, respectively, for ammonium nitrate and urea (Figure 4B).

In the stalk yield as influenced by $\mathrm{N}$ rate, there was an estimated maximum quadratic increase of 178.38 and $187.32 \mathrm{t} \mathrm{ha}^{-1}$ with 112.60 and $167.26 \mathrm{~kg} \mathrm{~N} \mathrm{ha}^{-1}$, corresponding to increases of 59.36 and $56.52 \mathrm{t} \mathrm{ha}^{-1}(33.27 \%$ and $30.17 \%)$, respectively, for ammonium nitrate and urea, compared to the control treatment, without any application of $\mathrm{N}$ (Figure 4C). As for pointer yield as a function of the $\mathrm{N}$ rate, there was an estimated maximum quadratic addition of 40.77 and $39.43 \mathrm{t} \mathrm{ha}^{-1}$ with 113.85 and $134.84 \mathrm{~kg} \mathrm{ha}^{-1}$ of $\mathrm{N}$, corresponding to increases of 16.87 and $17.60 \mathrm{t} \mathrm{ha}^{-1}(41.38 \%$ and $44.63 \%)$, respectively, for ammonium nitrate and urea, compared to the control treatment, without any application of $\mathrm{N}$ (Figure 4D).

In a recent study, the sugarcane productivity responses have been found to be affected by $\mathrm{N}$ fertilization; ref. [16] found in a dystrophic Oxisol a linear response of shoot yield at doses of ammonium nitrate $\left(0,50,100\right.$ and $\left.150 \mathrm{~kg} \mathrm{~N} \mathrm{ha}^{-1}\right)$. In other studies, with different conditions, in sandy soil (Hendry, FL, USA), ref. [59] found quadratic responses to $\mathrm{N}$ as ammonium nitrate that were higher than the current $\mathrm{N}$ recommendation $\left(202 \mathrm{~kg} \mathrm{~N} \mathrm{ha}^{-1}\right)$. These authors add that the effect of $\mathrm{N}$ response on stalk yield can be explained physiologically by changes in plant growth, the number of tillers, and in biomass production, which consequently affects the amount of sugar stored. Refs. $[17,60]$ mention that the response of the cane plant to $\mathrm{N}$ fertilization depends on several factors such as soil tillage type, organic matter $\mathrm{N}$, soil texture, and also the history of the use and management of soil, such as rotation with green manures, among other factors.

Considering irrigated environments in Brazil, studies carried out by [25] in Rio Largo, Alagoas, Brazil and by [24] in Jaú, São Paulo, Brazil the positive responses of sugarcane to the $\mathrm{N}$ application. The results obtained in these studies contrast with the $\mathrm{N}$ response curves obtained in recent studies 
with sugarcane under rainfed conditions, in which maximum stalk yields were reached at rates of 100 to $120 \mathrm{~kg} \mathrm{~N} \mathrm{ha}^{-1}[19,61]$. This is a fact that indicates that $\mathrm{N}$ fertilizer recommendations should be higher for environments with low water restriction (irrigated environments) compared to rainfed environments, because the potentials of crop productivity are higher $[23,24,62]$.
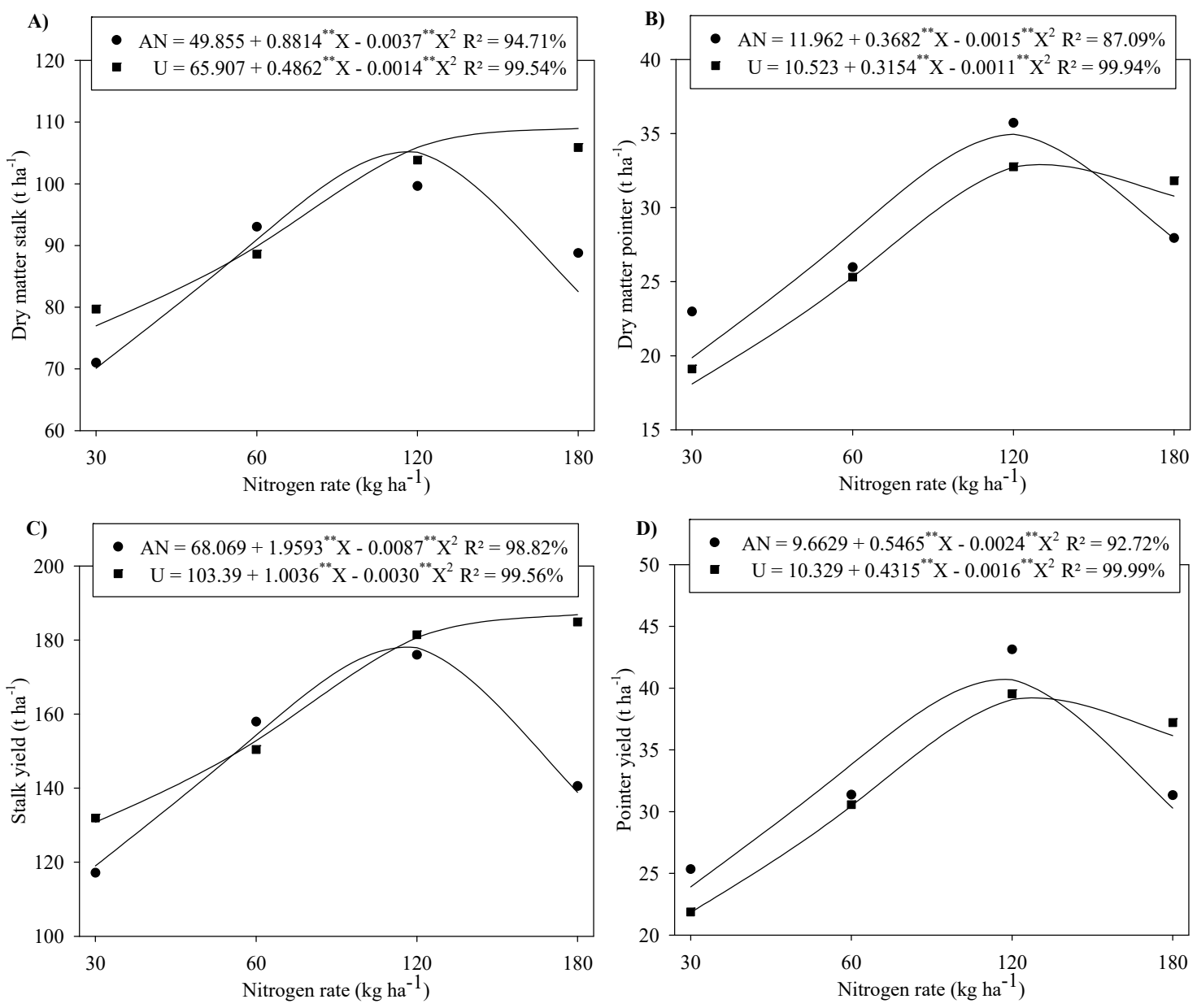

Figure 4. Dry matter stalk (A) and dry matter pointer of sugarcane (B), stalk yield (C), and pointer yield of sugarcane (D), in the cane plant cycle, as affected by $\mathrm{N}$ rate as ammonium nitrate (AN) and urea $(\mathrm{U}) .{ }^{* *}$ Significant respectively at $1 \%$ probability according to test $\mathrm{F}$.

A study showed that there are relevant distinctions in the levels and seasonal patterns of leaf $\mathrm{N}$ under high-input, irrigated conditions due to the effects of crop class and cultivar [63], and that high leaf $\mathrm{N}$ is difficult to maintain until the end of the season, even where maximum $\mathrm{N}$ accumulation is in excess of $200 \mathrm{~g} \mathrm{~N} \mathrm{~m}^{-2}$ [63].

Recent studies show that amongst the nitrogen level, an application of $125 \%$ the recommended dose was found to be optimum for the enhancement of cane yield, net returns, benefit/cost ratio, and nutrient use efficiency in plant and ratoon crops of sugarcane. The application of $\mathrm{N}$ fertilizer increased exchangeable $\mathrm{NH}_{4}{ }^{+}-\mathrm{N}$, hydrolysable $\mathrm{N}$, and total $\mathrm{N}$ with increasing levels of $\mathrm{N}$ fertilizer. Plant growth parameters and sugarcane yield were highly correlated with most of the $\mathrm{N}$ fractions (Kumar and Kumar [64]).

Field studies carried out in Florida (EUA) under Histosols (Coale et al., 1993 [65]) showed that at harvest, $71 \%$ of total dry matter and $55 \%$ of total accumulated $\mathrm{N}$ were removed from the field as millable sugarcane. 
However, to achieve high productivities with low costs and few impacts to the environment, a perfect interaction is required among abiotic factors, management, and the genetic potential of a variety.

In the sugarcane-producing regions of Brazil, the volume of irregularly distributed rainfall, in addition to the diversity of soils cultivated with this culture, which have chemical characteristics and varied physics, has justified research in the selection of varieties adapted to different edaphic and climatic conditions. Research has also led to the adoption of irrigation in the cane fields, which leads to the selection of sugarcane varieties in which the decision is not restricted only to the productive potential, but also considers the plant's ability to efficiently transform the nutrients absorbed in biomass. This is important especially for nitrogen, which has a high cost and most of what is consumed in the country is imported, in addition to its susceptibility to losses and it being a potential pollutant of the environment.

\section{Conclusions}

Under the conditions of the present study, it was observed that for the sugarcane irrigated variety evaluated (IACSP95-5000), in the cane plant cycle, grown under Cerrado (Savannah) Oxisol, the urea $\mathrm{N}$ source is superior to the ammonium nitrate in the accumulation of $\mathrm{N}$ and in the amount of $\mathrm{N}$ from the soil native $\mathrm{N}$ at the rates of 30 and $180 \mathrm{~kg} \mathrm{~N} \mathrm{ha}^{-1}$, in the sugarcane irrigated condition. The average fertilizer $\mathrm{N}$ utilization by sugarcane (IACSP95-5000 variety) was $60.17 \%$ for the ammonium nitrate source and $44.95 \%$ for urea. The $\mathrm{N}$ rate giving the best results is $136.87 \mathrm{~kg} \mathrm{~N} \mathrm{ha}^{-1}$ for ammonium nitrate and $137.92 \mathrm{~kg} \mathrm{~N} \mathrm{ha}^{-1}$ for urea. The responses in the percentage and quantity of $\mathrm{N}$ in the sugarcane from fertilizer increases with the increasing $\mathrm{N}$ rate. The amount of $\mathrm{N}$ in the plant from the soil native $\mathrm{N}$ is higher than that from fertilizer $\mathrm{N}$. The soil was the main $\mathrm{N}$ source for sugarcane. The higher stalk and pointer yield occurred at the average dose of $143.61 \mathrm{~kg} \mathrm{~N} \mathrm{ha}^{-1}$, with an average increase of $25.87 \%$ in relation to control treatment (without $\mathrm{N}$ application). Further studies are needed to evaluate the residual effect of $\mathrm{N}$ in the next cycles.

Author Contributions: The authors N.F.d.S., E.C.d.S., T.M., M.B.T., F.A.L.S., F.N.C., J.A.-G. and W.S.d.S.C. have contributed equally to the research design, development, and the writing of the manuscript. All authors have read and agreed to the published version of the manuscript.

Funding: This research was funded by National Council for Scientific and Technological Development-CNPq grant number 305218, Ministry of Science, Technology, Innovation, and Communications-MCTIC grant number 446999, the Coordination for the Improvement for Higher Level Personnel-CAPES, the Research Support Foundation of the State of Goiás-FAPEG and the APC was funded by Federal Institute of Education, Science, and Technology Goiano (IFGoiano)-Campus Rio Verde.

Acknowledgments: The authors would like to thank the Conselho Nacional de Desenvolvimento Científico e Tecnológico (CNPq) and the Coordination for Upgrading Higher Institution Personnel (CAPES) for the financial support and research fellowship; to the International Atomic Energy Agency (IAEA/Project ARCAL RLA 5065), to the Foundation for Research Support of the State of Goiás (FAPEG), the Raízen Plant Jataí unit, and the Federal Institute of Education, Science and Technology Goiano (IF Goiano)—Campus Rio Verde, Gois, Brazil for financial support.

Conflicts of Interest: The authors declare no conflict of interest.

\section{References}

1. Companhia Nacional De Abastecimento (Conab). Acompanhamento da safra brasileira de cana-de-açúcar 2019/2020. Available online: https://www.conab.gov.br/info-agro/safras/cana (accessed on 12 March 2019).

2. Agrostat (Estatísticas de Comercio Exterior do Agronegócio Brasileiro). Ministério da Agricultura Pecuária e Abastecimento. Available online: http://indicadores.agricultura.gov.br/agrostat/index.htm (accessed on 12 March 2019).

3. Lassaletta, L.; Billen, G.; Garnier, J.; Bouwman, L.; Velazquez, E.; Mueller, N.D.; Gerber, J.S. Nitrogen use in the global food system: Past trends and future trajectories of agronomic performance, pollution, trade, and dietary demand. Environ. Res. Lett. 2016, 11, 095007. [CrossRef] 
4. Schils, R.; Olesen, J.E.; Kersebaum, K.C.; Rijk, B.; Oberforster, M.; Kalyada, V.; Khitrykau, M.; Gobin, A.; Kirchev, H.; Manolova, V.; et al. Cereal yield gaps across Europe. Eur. J. Agron. 2018, 101, 109-120. [CrossRef]

5. Cantarella, H.; Trivelin, P.C.O.; Vitti, A.C. Nitrogênio e enxofre na cultura da cana-de-açúcar. In Nitrogênio e Enxofre na Agricultura Brasileira; Yamada, T., Abdalla, S.R.S., Vitti, G.C., Eds.; IPNI Brasil: Piracicaba, Brazil, 2007; pp. 355-412.

6. Vitti, A.C.; Franco, H.C.J.; Trivelin, P.C.O.; Ferreira, D.A.; Otto, R.; Fortes, C.; Faroni, C.E. Nitrogênio proveniente da adubação nitrogenada e de resíduos culturais na nutrição da cana-planta. Pesqui. Agropecuária Bras. 2011, 46, 287-293. [CrossRef]

7. Holst, J.; Brackina, R.; Robinsona, N.; Lakshmananb, P.; Schmidta, S. Soluble inorganic and organic nitrogen in two Australian soils under sugarcane cultivation. Agric. Ecosyst. Environ. 2012, 155, 16-26. [CrossRef]

8. Trivelin, P.C.O.; Franco, H.C.J.; Otto, R.; Ferreira, D.A.; Vitti, A.C.; Fortes, C.; Faroni, C.E.; Oliveira, E.C.A.; Cantarella, E. Impact of sugarcane trash on fertilizer requirements for São Paulo, Brazil. Sci. Agric. 2013, 70, 345-352. [CrossRef]

9. Rosolem, C.A.; Ritz, K.; Cantarella, H.; Galdos, M.V.; Hawkesford, M.J.; Whalley, W.R.; Mooney, S.J. Enhanced Plant Rooting and Crop System Management for Improved N Use Efficiency. Adv. Agron. 2017, 146, 205-239. [CrossRef]

10. Silva, A.G.B.; Sequeira, C.H.; Sermarini, R.A.; Otto, R. Urease Inhibitor NBPT on Ammonia Volatilization and Crop Productivity: A Meta-Analysis. Agron. J. 2017, 109, 1-13. [CrossRef]

11. De Mira, A.B.; Cantarella, H.; Souza-Netto, G.; Moreira, L.; Kamogawa, M.; Otto, R. Optimizing urease inhibitor usage to reduce ammonia emission following urea application over crop residues. Agric. Ecosyst. Environ. 2017, 248, 105-112. [CrossRef]

12. Cantarella, H.; Otto, R.; Soares, J.; Silva, A.G.D.B. Agronomic efficiency of NBPT as a urease inhibitor: A review. J. Adv. Res. 2018, 13, 19-27. [CrossRef]

13. Martins, M.; Sant'Anna, S.; Zaman, M.; Santos, R.; Monteiro, R.; Alves, B.; Jantalia, C.; Boddey, R.; Urquiaga, S. Strategies for the use of urease and nitrification inhibitors with urea: Impact on $\mathrm{N}_{2} \mathrm{O}$ and $\mathrm{NH}_{3}$ emissions, fertilizer- ${ }^{15} \mathrm{~N}$ recovery and maize yield in a tropical soil. Agric. Ecosyst. Environ. 2017, 247, 54-62. [CrossRef]

14. Awale, R.; Chatterjee, A. Enhanced Efficiency Nitrogen Products Influence Ammonia Volatilization and Nitrous Oxide Emission from Two Contrasting Soils. Agron. J. 2017, 109, 47-57. [CrossRef]

15. Snyder, C.S. Enhanced nitrogen fertilizer technologies support the ' $4 \mathrm{R}$ ' concept to inimize crop production and inimize environmental losses. Soil Res. 2017, 55, 463-472. [CrossRef]

16. Fortes, C.; Trivelin, P.C.O.; Vitti, A.C.; Otto, R.; Franco, H.C.J.; Faroni, C.E. Stalk and sucrose yield in response to nitrogen fertilization of sugarcane under reduced tillage. Pesqui. Agropecuária Bras. 2013, 48, 88-96. [CrossRef]

17. Franco, H.C.J.; Trivelin, P.C.O.; Eduardo, F.C.; Vitti, A.C.; Otto, R. Stalk yield and technological attributes of planted cane as related to nitrogen fertilization. Sci. Agric. 2010, 67, 579-590. [CrossRef]

18. Franco, H.C.J.; Vitti, A.C.; Faroni, C.E.; Cantarella, H.; Trivelin, P.C.O. Estoque de nutrientes em resíduos culturais incorporados ao solo na reforma de áreas com cana-de-açúcar. STAB-Açúcar, Álcool e Subprodutos 2007, 25, 32-36.

19. Vitti, A.C.; Trivelin, P.C.O.; Gava, G.J.C.; Penatti, C.P.; Bologna, I.R.; Faroni, C.E.; Franco, H.C.J. Produtividade da cana-de-açúcar relacionada ao nitrogênio residual da adubação e do sistema radicular. Pesqui. Agropecuária Bras. 2007, 42, 249-256. [CrossRef]

20. Galindo, F.S.; Filho, M.T.; Buzetti, S.; Pagliari, P.H.; Santini, J.M.K.; Alves, C.J.; Megda, M.M.; Nogueira, T.A.R.; Andreotti, M.; Arf, O. Maize Yield Response to Nitrogen Rates and Sources Associated with Azospirillum brasilense. Agron. J. 2019, 111, 1985-1997. [CrossRef]

21. Gil, J.D.B.; Garrett, R.D.; Rotz, A.; Daioglou, V.; Valentim, J.; Pires, G.F.; Costa, M.H.; Lopes, L.; Reis, J.C. Tradeoffs in the quest for climate smart agricultural intensification in Mato Grosso, Brazil. Environ. Res. Lett. 2018, 13, 064025. [CrossRef]

22. Trivelin, P.C.O.; Victoria, R.L.; Rodrigues, J.C.S. Aproveitamento por soqueira de cana-de-açúcar de final de safra do nitrogênio da aquamônia-15N e ureia-15N aplicado ao solo em complemento à vinhaça. Pesquisa Agropecuária Brasileira 1995, 30, 1375-1385.

23. Oliveira, E.C.A.D.; Freire, F.J.; Oliveira, R.I.D.; Oliveira, A.C.D.; Freire, M.B.G.D.S. Acúmulo e alocação de nutrientes em cana-de-açúcar. Revista Ciência Agronômica 2011, 42, 579-588. 
24. Gava, G.J.C.; Kölln, O.T.; Uribe, R.A.M.; Trivelin, P.C.O.; Cantarella, H. Interação entre água e nitrogênio na produtividade de cana-de-açúcar (Saccharum sp.). In Tópicos em Ecofisiolgia da Cana-De-Açúcar, 1st ed.; FEPAF: Botucatu, Brazil, 2010; Volume 1, pp. 49-66.

25. Teodoro, I. Respostas Técnico-Econômicas da Cana-De-Açúcar a Níveis de Irrigação e Adubação Nitrogenada. Ph.D. Thesis, Universidade Federal de Campina Grande, Campina Grande, Paraíba, Brazil, 2011; p. 100.

26. Kölln, O.T. Interação Entre os Estresses de Nitrogênio e Disponibilidade Hídrica no Fracionamento Isotópico de 13C e na Produtividade em Soqueira de Cana-De-Açúcar. Master's Thesis, Universidade de São Paulo, São Paulo, Brazil, 2012; p. 104.

27. Basanta, M.; Dourado-Neto, D.; Reichardt, K.; Bacchi, O.; Oliveira, J.; Trivelin, P.; Timm, L.C.; Tominaga, T.; Correchel, V.; Pires, L.; et al. Management effects on nitrogen recovery in a sugarcane crop grown in Brazil. Geoderma 2003, 116, 235-248. [CrossRef]

28. Oliveira, A.C. Interação da Adubação Nitrogenada e Molíbdica em Cana-De-Açúcar. Ph.D. Thesis, Universidade Federal Rural de Pernambuco, Recife, Pernambuco, Brazil, 2012; p. 96.

29. Franco, H.C.J.; Trivelin, P.C.O.; Faroni, C.E.; Vitti, A.C.; Otto, R. Aproveitamento pela cana-de-açúcar da adubação nitrogenada de plantio. Rev. Bras. De Ciência Do Solo 2008, 32, 2763-2770. [CrossRef]

30. Köppen, W.; Geiger, R. Klimate der Erde; Verlag Justus Perthes: Gotha, Germany, 1928.

31. Soil Survey Staff. Keys to Soil Taxonomy, 11th ed.; United States Department of Agriculture, Natural Resources Conservation Service: Washington, WA, USA, 2010; p. 338.

32. Santos, H.G.; Jacomine, P.K.T.; Anjos, L.H.C.; Oliveira, V.A.; Lumbreras, J.F.; Coelho, M.R.; Almeida, J.A.; Cunha, T.J.F.; Oliveira, J.B. Sistema brasileiro de classificação de solos. In Centro Nacional de Pesquisa de Solos, 5th ed.; Embrapa Produção de Informação: Brasília, Brazil; Embrapa Solos: Rio de Janeiro, Brazil, 2018; p. 588.

33. Sousa, D.M.G.; Lobato, E. (Eds.) Cerrado: Correção do Solo e adubação, 2nd ed.; Embrapa Informação Tecnológica/Embrapa-CPA: Brasília, Brazil, 2004; p. 416.

34. Allen, R.G.; Jensen, M.E.; Wright, J.L.; Burman, R.D. Operational Estimates of Reference Evapotranspiration. Agron. J. 1907, 81, 650-662. [CrossRef]

35. Rossetto, R. Maturação da Cana-De-Açúcar. 2012. Available online: http://www.agencia.cnptia.embrapa.br/ gestor/cana-de-acucar/arvore/CONTAG01_90_22122006154841.html (accessed on 10 January 2017).

36. Barrie, A.; Prosser, S.J. Automated analysis of light-element stable isotopes by isotope ratio mass spectrometry. In Mass Spectrometry of Soils; Boutton, T.W., Yamasaki, S., Eds.; Marcel Dekker: New York, NY, USA, 1996; pp. 1-46.

37. International Atomic Energy Agency-IAEA. Use of Isotope and Radiation Methods in Soil and Water Management and Crop Nutrition, Training course series No. 14; IAEA: Vienna, Austria, 2001.

38. SAS Institute Incorporation. The SAS-System for Windows Release 8.02 (TS2M0) (Software); SAS Institute Inc.: Cary, NC, USA, 2001.

39. Doorenbos, J.; Kassam, A.; Bentvelsen, C.; Uittenbogaard, G. Yield Response to Water. In Irrigation and Agricultural Development, paper 33; FAO: Rome, Italy, 1980; pp. 257-280.

40. Oliveira, E.C.A.D.; Freire, F.J.; Oliveira, R.I.D.; Freire, M.B.G.D.S.; Neto, D.E.S.; Silva, S.A.M.D. Extração e exportação de nutrientes por variedades de cana-de-açúcar cultivadas sob irrigação plena. Rev. Bras. De Ciência Do Solo 2010, 34, 1343-1352. [CrossRef]

41. Gava, G.J.C.; Trivelin, P.C.O.; Vitti, A.C.; Oliveira, M.W. Recuperação do nitrogênio (15N) da uréia e da palhada por soqueira de cana-de-açúcar (Saccharum spp.). Rev. Bras. De Ciência Do Solo 2003, 27, 621-630. [CrossRef]

42. Taiz, L.; Zeiger, E. Fisiologia Vegetal, 5th ed.; Artmed: Porto Alegre, Brazil, 2013; p. 954.

43. Richardson, A.E.; Barea, J.M.; McNeill, A.M.; Prigent-Combaret, C. Acquisition of phosphorus and nitrogen in the rhizosphere and plant growth promotion by microorganisms. Plant Soil 2009, 321, 305-339. [CrossRef]

44. Robinson, N.; Brackin, R.; Vinall, K.; Soper, F.; Holst, J.; Gamage, H.; Paungfoo-Lonhienne, C.; Renneberg, H.; Lakshmanan, P.; Schmidt, S. Nitrate Paradigm Does Not Hold Up for Sugarcane. PLoS ONE 2011, 6, e19045. [CrossRef]

45. Dourado-Neto, D.; Powlson, D.; Abu Bakar, R.; Bacchi, O.O.S.; Basanta, M.; Cong, P.T.; Keerthisinghe, G.; Ismaili, M.; Rahman, S.M.; Reichardt, K.; et al. Multiseason Recoveries of Organic and Inorganic Nitrogen-15 in Tropical Cropping Systems. Soil Sci. Soc. Am. J. 2010, 74, 139-152. [CrossRef] 
46. Da Silva, N.F.; Cunha, F.N.; De Oliveira, R.C.; Moura, L.M.D.F.; De Moura, L.C.; Teixeira, M.B.; Bastos, F.J.D.C. Crescimento da cana-de-açúcar sob aplicação de nitrogênio via gotejamento subsuperficial. Rev. Bras. De Agric. Irrig. 2014, 8, 1-11. [CrossRef]

47. Liu, X.-E.; Li, X.G.; Guo, R.-Y.; Kuzyakov, Y.; Li, F. The effect of plastic mulch on the fate of urea-N in rain-fed maize production in a semiarid environment as assessed by 15N-labeling. Eur. J. Agron. 2015, 70, 71-77. [CrossRef]

48. Smith, C.J.; Chalk, P.M. The residual value of fertilizer N in crop sequences: An appraisal of 60 years of research using $15 \mathrm{~N}$ tracer. Field Crop. Res. 2018, 217, 66-74. [CrossRef]

49. Carvalho, E.X. Ciclagem de Nitrogênio e Estimativa de Biomassa de Cana-De-Açúcar em Pernambuco. Ph.D. Thesis, Universidade Federal de Pernambuco, Recife, Brazil, 2015; p. 71.

50. Moreira, F.M.S.; Siqueira, J.O. Microbiologia e Bioquímica do Solo; Editora UFLA: Lavras, Brzail, $2002 ;$ p. 625.

51. Franco, H.C.J.; Otto, R.; Faroni, C.E.; Vitti, A.C.; Oliveira, E.C.A.D.; Trivelin, P.C.O. Nitrogen in sugarcane derived from fertilizer under Brazilian field conditions. Field Crop. Res. 2011, 121, 29-41. [CrossRef]

52. Prasertsak, P.; Freney, J.; Denmead, O.; Saffigna, P.; Prove, B.; Reghenzani, J. Effect of fertilizer placement on nitrogen loss from sugarcane in tropical Queensland. Nutr. Cycl. Agroecosyst. 2002, 62, 229-239. [CrossRef]

53. Otto, R.; Mulvaney, R.L.; Khan, S.A.; Trivelin, P.C.O. Quantifying soil nitrogen mineralization to improve fertilizer nitrogen management of sugarcane. Boil. Fertil. Soils 2013, 49, 893-904. [CrossRef]

54. Megda, M.M.; Mariano, E.; Leite, J.M.; Franco, H.C.J.; Vitti, A.C.; Megda, M.M.; Khan, S.A.; Mulvaney, R.L.; Trivelin, P.C.O. Contribution of fertilizer nitrogen to the total nitrogen extracted by sugarcane under Brazilian field conditions. Nutr. Cycl. Agroecosyst. 2015, 101, 241-257. [CrossRef]

55. Mariano, E.; Leite, J.M.; Megda, M.X.V.; Torres-Dorante, L.; Trivelin, P.C.O. Influence of Nitrogen Form Supply on Soil Mineral Nitrogen Dynamics, Nitrogen Uptake, and Productivity of Sugarcane. Agron. J. 2015, 107, 641-650. [CrossRef]

56. Herridge, D.F.; Peoples, M.B.; Boddey, R.M. Global inputs of biological nitrogen fixation in agricultural systems. Plant Soil 2008, 311, 1-18. [CrossRef]

57. Urquiaga, S.; Xavier, R.P.; De Morais, R.F.; Batista, R.B.; Schultz, N.; Leite, J.M.; E Sá, J.M.; Barbosa, K.P.; De Resende, A.S.; Alves, B.J.R.; et al. Evidence from field nitrogen balance and $15 \mathrm{~N}$ natural abundance data for the contribution of biological N2 fixation to Brazilian sugarcane varieties. Plant Soil 2011, 356, 5-21. [CrossRef]

58. Olk, D.C. Organic forms of soil nitrogen. In Nitrogen in Agricultural Systems, Agronomy Monograph, 49; Schepers, J.S., Raun, W.R., Eds.; ASA-CSSA-SSSA: Madison, WI, USA, 2008; pp. 57-100.

59. McCray, J.M.; Morgan, K.T.; Baucum, L.; Ji, S. Sugarcane Yield Response to Nitrogen on Sand Soils. Agron. J. 2014, 106, 1461-1469. [CrossRef]

60. Bologna-Campbell, I. Balanço de Nitrogênio e Enxofre no Sistema Solo-Cana-de-Açúcar no Ciclo de Cana-Planta. Ph.D. Thesis, Universidade de São Paulo, São Paulo, Brazil, 2007; p. 112.

61. Rossetto, R.; Dias, F.L.F.; Landell, M.G.A.; Cantarella, H.; Tavares, S.; Vitti, A.C.; Perecin, D. N and K fertilisation of sugarcane ratoons harvested without burning. In Proceedings of the International Society of Sugar Cane Technologists, Veracruz, Mexico, 7-11 March 2010; Volume 27, pp. 1-8.

62. Júnior, A.S.D.A.; Bastos, E.A.; Ribeiro, V.Q.; Duarte, J.A.L.; Braga, D.L.; Noleto, D.H. Níveis de água, nitrogênio e potássio por gotejamento subsuperficial em cana-de-açúcar. Pesqui. Agropecuária Bras. 2012, 47, 76-84. [CrossRef]

63. Wood, A.W.; Muchow, R.C.; Robertson, M.J. Growth of sugarcane under high input conditions in tropical Australia. III. Accumulation, partitioning and use of nitrogen. Field Crop. Res. 1996, 48, 223-233. [CrossRef]

64. Kumar, N.; Kumar, V. Production Potential and Nitrogen Fractionation of Sugarcane-Based Cropping System as Influenced by Planting Materials and Nitrogen Nutrition. Sugar Tech 2020, 1-8. [CrossRef]

65. Coale, F.J.; Sanchez, C.A.; Izuno, F.T.; Bottcher, A.B. Nutrient Accumulation and Removal by Sugarcane Grown on Everglades Histosols. Agron. J. 1907, 85, 310-315. [CrossRef]

(C) 2020 by the authors. Licensee MDPI, Basel, Switzerland. This article is an open access article distributed under the terms and conditions of the Creative Commons Attribution (CC BY) license (http://creativecommons.org/licenses/by/4.0/). 